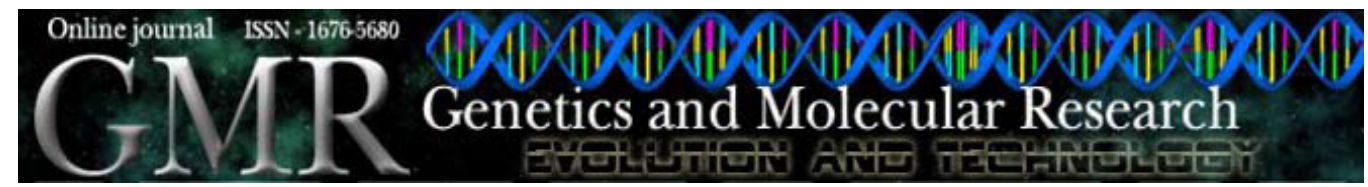

\title{
Concurrent sequence variation of TP53 and TP73 genes in anaplastic astrocytoma
}

\author{
N.P. Anselmo1,4, J.A. Rey ${ }^{2}$, L.O. Almeida ${ }^{1}$, A.C. Custódio ${ }^{1}$, \\ J.R.W. Almeida ${ }^{3}$, C.A. Clara ${ }^{3}$, M.J. Santos ${ }^{3}$ and C. Casartelli ${ }^{1}$ \\ ${ }^{1}$ Departamento de Genética, Laboratório de Oncogenética, \\ Faculdade de Medicina de Ribeirão Preto, Universidade de São Paulo, \\ Ribeirão Preto, SP, Brasil \\ 2Unidad de Investigación, Hospital Universitário "La Paz", Madrid, Espanha \\ ${ }^{3}$ Fundação Pio XII, Hospital de Câncer de Barretos, Barretos, SP, Brasil \\ ${ }^{4}$ Instituto de Ciências Biológicas, Universidade Federal do Pará, \\ Belém, PA, Brasil \\ Corresponding author: C. Casartelli \\ E-mail: ccasart@fmrp.usp.br
}

Genet. Mol. Res. 8 (4): 1257-1263 (2009)

Received April 29, 2009

Accepted July 13, 2009

Published October 20, 2009

\begin{abstract}
Disruption or loss of tumor suppressor gene TP53 is implicated in the development or progression of almost all different types of human malignancies. Other members of the p53 family have been identified. One member, p73, not only shares a high degree of similarity with p53 in its primary sequence, but also has similar functions. Like p53, p73 can bind to DNA and activate transcription. Using PCR-SSCP and gene sequencing, we analyzed the TP53 and TP73 genes in a case of a grade III anaplastic astrocytoma that progressed to glioblastoma. We found a deletion of AAG at position 595-597 of TP53 (exon 6), resulting in the deletion of Glu 199 in the protein and a genomic polymorphism of TP73, identified as an A-to-G change, at position E8/+15 at intron 8 (IVS8-15A>G). The mutation found at exon 6 of the gene TP53 could be associated with the rapid tumoral progression found in this case, since the mutated p53 may inactivate the wild-type $\mathrm{p} 53$ and the $\mathrm{p} 73 \alpha$ protein, which was conserved here, leading to an increase in cellular instability.
\end{abstract}

Key words: Astrocytoma; TP53 gene; TP73 gene 


\section{INTRODUCTION}

Gliomas, tumors of neuroectodermal origin, range from very "benign" astrocytomas to highly malignant glioblastoma multiforme, organized as an intermixed continuum rather than as discrete entities. Even low-grade gliomas may recur a few years later as a glioblastoma multiforme (Holland and Frei III, 1982). In astrocytic tumors, there is evidence that different genetic pathways lead to glioblastoma multiforme as a common end point. There appears to be two types of glioblastoma multiforme, denominated "primary" and "secondary" (Kleihues, 1998; Ohgaki and Kleihues, 2007).

Primary glioblastomas develop rapidly de novo, without clinical or histological evidence of a less malignant precursor lesion. They mainly affect the elderly and are genetically characterized by loss of heterozygosity $10 \mathrm{q}$ ( $70 \%$ of cases), EGFR amplification (36\%), p16 $6^{I N K 4 \alpha}$ deletion (31\%), and PTEN mutations (25\%). Secondary glioblastomas develop through progression from low-grade diffuse astrocytoma or anaplastic astrocytoma and manifest in younger patients. In the pathway to secondary glioblastoma, TP53 mutations are the most frequent and earliest detectable genetic alterations, already present in $60 \%$ of precursor low-grade astrocytomas. Loss of heterozygosity of chromosome 17 and mutations in the gene frequently occur in low-grade astrocytomas and identical TP53 mutations can be detected when these low-grade tumors progress to anaplastic astrocytomas and glioblastomas (Sidransky et al., 1992; Reifenberger et al., 1996). During progression to glioblastoma, additional mutations accumulate, including loss of heterozygosity 10q25-qter $(\sim 70 \%)$, which is the most frequent genetic alteration in both primary and secondary glioblastomas (Michael and Prados, 2000; Ohgaki and Kleihues, 2007).

The TP53 gene family consists of three genes TP53, TP63, and TP73, which have nonoverlapping functions in pivotal cellular processes, such as DNA synthesis and repair, growth arrest, apoptosis or senescence, genome stability, angiogenesis, development, and differentiation (Farmer et al., 1992; Levrero et al., 1999; Vogelstein et al., 2000; Vousden and Lu, 2002; Sbisá et al., 2007). These activities have been linked to the ability of $\mathrm{p} 53$ to bind to specific DNA sequences and activate transcription (Ko and Prives, 1996).

These genes encode sequence-specific nuclear transcription factors that recognize the same responsive element in their target genes (Bourdon et al., 1997).

The TP53, TP73, and TP63 genes, through alternative splicing, can produce different isoforms, which differ in the C-terminal portion (De Laurenzi et al., 1999; Ueda et al., 1999; Bourdon et al., 2005).

It has been suggested that while the main role of TP53 lies in the inhibition of tumor progression TP73, TP63 appears to be much more strongly involved in development and differentiation (D'Erchia et al., 2003; Melino et al., 2003). The wild-type p53 protein is important in many cellular events, including upregulation of expression of the p21 protein and inhibition of cyclin-dependent kinases (Haas-Kogan et al., 1996; Gomez-Manzano et al., 1997). The TP53 gene, found on chromosome $17 \mathrm{p} 13$, is frequently altered, often by point mutations and deletions in over 30 to $49 \%$ of cases, including lower-grade gliomas, suggesting an early, perhaps initiating event in malignant transformation (Watanabe et al., 1997).

The gene TP73 not only shares a high degree of similarity with TP53 in its primary sequence, but also seems to exhibit similar functions (Zhu et al., 1998; Arrowsmith, 1999). Given that they share amino acid sequence identity in the DNA-binding domain, TP53 and TP73 should have redundant functions in the regulation of gene expression. Indeed, p73 can activate TP53-regulated genes and suppress growth or induce apoptosis. Moreover, TP53 and TP73 are both induced by 
DNA damage, albeit through distinct mechanisms. Because p53 and p73 are linked to different upstream pathways, this family of transcription factors might regulate a common set of genes in response to different extracellular signals and developmental cues (Levrero et al., 2000). We made an analysis of TP53 and TP73 $\alpha$ genes in a case of grade III anaplastic astrocytoma that had a further progression to glioblastoma.

\section{SUBJECT AND METHODS}

A 30-year-old male patient was operated for a WHO grade III anaplastic astrocytoma. One year later, there was a recurrence and the diagnosis was a WHO anaplastic glioblastoma (grade later III) and a WHO grade IV glioblastoma. High-molecular weight DNA was extracted from normal and tumor tissues by standard methods (Rey et al., 1992) and pathological tissues were classified by histological examination and graded according to WHO guidelines (Kleihues and Cavenee, 2000).

Genomic polymerase chain reaction (PCR) amplification was performed on exons 5, 6, 7, and 8-9 of the TP53 gene and on exons 3, 4, 6, 7, 8, and 9 of the TP73 gene. Table 1 shows the primers used for these genes. PCR conditions for $T P 53$ were 35 cycles of $95^{\circ} \mathrm{C}$ for $1 \mathrm{~min}, 57-61^{\circ} \mathrm{C}$ for $1 \mathrm{~min}$ and $72^{\circ} \mathrm{C}$ for $2 \mathrm{~min}$, with a final extension of $8 \mathrm{~min}$ at $72^{\circ} \mathrm{C}$. PCR conditions for $T P 73$ were 35 cycles of $94^{\circ} \mathrm{C}$ for $30 \mathrm{~s}, 57-61^{\circ} \mathrm{C}$ for $30 \mathrm{~s}$ and $72^{\circ} \mathrm{C}$ for $90 \mathrm{~s}$, with a final extension of $7 \mathrm{~min}$ at $72^{\circ} \mathrm{C}$. The PCR products were loaded onto $6-12 \%$ non-denaturing polyacrylamide gels (with or without $10 \%$ glycerol), electrophoresed and then silver stained (von Deimling et al., 1993). Samples displaying an altered PCR-SSCP (single-strand conformation polymorphism) pattern were re-amplified by PCR with the same set of primers, and the PCR products were sequenced with the ABI PRISM Big Dye Terminator Cycles Sequencing Kit (Perking Elmer, CA, USA). Each amplicon was sequenced bidirectionally.

\begin{tabular}{|c|c|c|}
\hline \multicolumn{3}{|c|}{ TP53 } \\
\hline Exon & Sequence (5'- 3') & Amplified fragment \\
\hline 5 & $\begin{array}{l}\text { F - 5' - TTCACTTGTGCCCTGACTT - 3', } \\
\text { R - 5' - AACCAGCCCTGTCCGTCTC - 3' }\end{array}$ & 269 bp \\
\hline 6 & $\begin{array}{l}\text { F - 5' - GGGCTGGTTGCCCAGGGT - 3' } \\
\text { R - 5' - TAGTTGCAAACCAGACCTC - 3' }\end{array}$ & $221 \mathrm{bp}$ \\
\hline 7 & $\begin{array}{l}\text { F - 5' - GTGTTA(G)TCTCCTAGGTTG - 3, } \\
\text { R - 5' - TGGCAAGTGGCTCCTGAC - 3, }\end{array}$ & 193 bp \\
\hline $8-9$ & $\begin{array}{l}\text { F - 5' - CCTTACTGCCTCTTGCTTC - 3' } \\
\text { R - 5' - CTGGAAACTTTCCACTTGAT - 3' }\end{array}$ & 384 bp \\
\hline \multicolumn{3}{|c|}{$T P 73 \alpha$} \\
\hline Exon & Sequence (5'-3') & Amplified fragment \\
\hline 3 & $\begin{array}{l}\text { F - 5' - TGACACCCAAACTGGGGACTGA - 3' } \\
\text { R - 5' - CCACTCCAGTCCTCTTGCAGA - } 3\end{array}$ & $213 \mathrm{bp}$ \\
\hline 4 & $\begin{array}{l}\text { F - 5' - GACGACTGACTGTGTTGTGTTTC - 3' } \\
\text { R - 5' - CTCAGGGACTAGGGGAACTC - 3' }\end{array}$ & 267 bp \\
\hline 6 & $\begin{array}{l}\text { F - 5', - ACCTCTATGCACCTCTCTGAAG - 3' } \\
\text { R - 5' - GACCCGTACAGCTGACTGCA - 3' }\end{array}$ & 213 bp \\
\hline 7 & $\begin{array}{l}\text { F - 5', TTGGGGCTGCGTGCTGATGCTA - 3', } \\
\text { R - 5' - CCTGCAGGTCTCCATGACAGCT - 3' }\end{array}$ & 267 bp \\
\hline 8 & $\begin{array}{l}\text { F - 5', CAGGGTTGAGCTCACAATTCTG - } 3 \\
\text { R - 5' - TCCTCCCACACGCGTCCAGTT - } 3\end{array}$ & 234 bp \\
\hline 9 & $\begin{array}{l}\text { F - 5' - ACCCTCTGGTCCTGCCTGCTCA - 3', } \\
\text { R - 5' - ACGACAGAGGTGAGGCAGGTCT - 3' }\end{array}$ & 192 bp \\
\hline
\end{tabular}




\section{RESULTS}

Using PCR-SSCP methods, we detected aberrantly migrated bands in two exons (one from TP53 and one from TP73) (Figure 1A and C) and nucleotide sequence analysis revealed two types of changes (Table 2). The first was a polymorphism identified as an A-to-G change, at position $\mathrm{E} 8 /+15$ of intron 8 (IVS8-15A $>\mathrm{G}$ ) in the TP73 gene (Figure 1B); another alteration was a deletion of AAG in the position 595-597 of TP53 (Figure 1D), resulting in the deletion of Glu 199 in the protein.
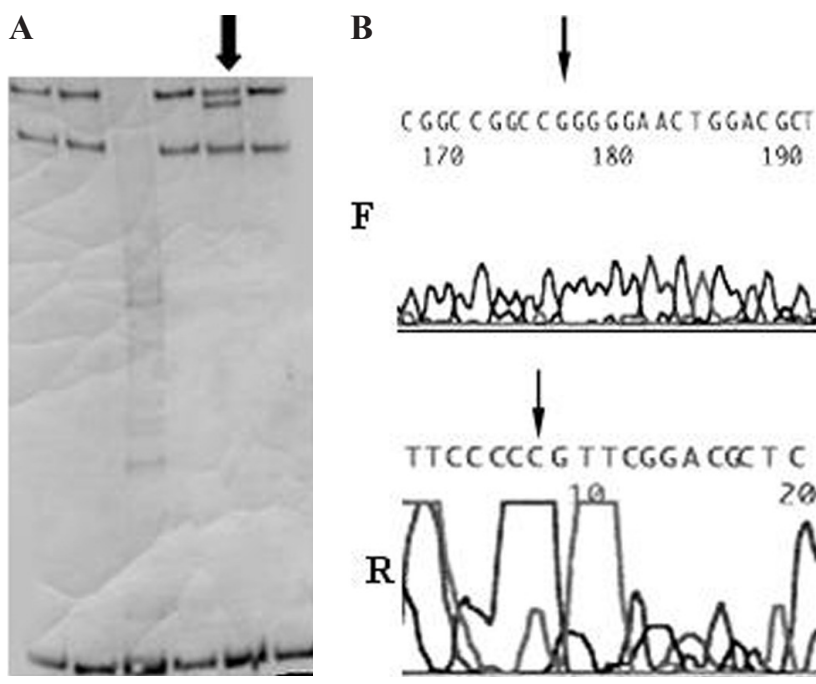

$\mathbf{F}$
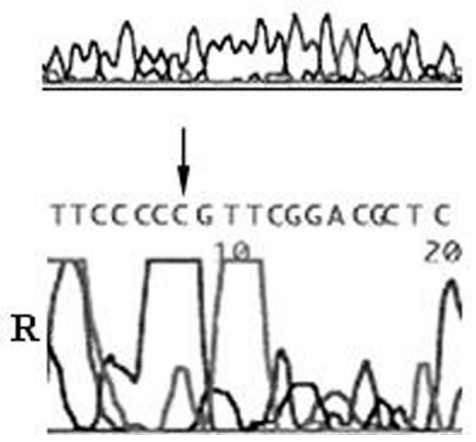

C

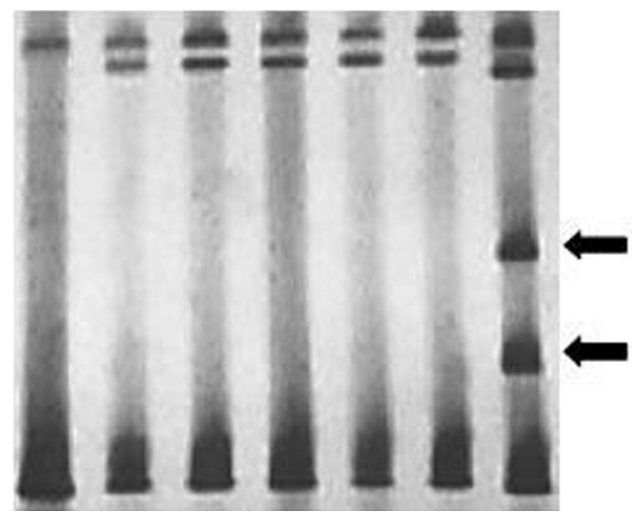

D

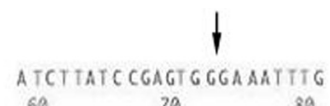

F

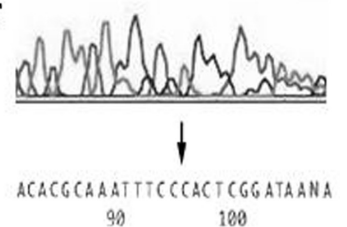

$\mathbf{R}$

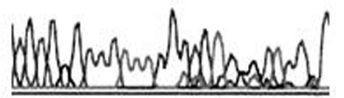

Figure 1. A. Exons 8-9 of the $T P 73$ gene. Arrow shows different mobility. B. Sequencing analysis shows (arrows) the genomic polymorphism of TP73, an A-to-G change, at position E8/+15 at intron 8 (IVS8-15A $>$ G). C. Exon 6 of the TP53 gene. Arrows show different motilities. D. Sequencing analysis shows (arrows) the deletion of AAG at position 595-597 del AAG/Glu in exon 6 of TP53. $\mathrm{F}$ = forward; $\mathrm{R}=$ reverse. 
Table 2. Sequence variation identified in the TP53 and TP73 genes in anaplastic astrocytoma.

\begin{tabular}{lccc}
\hline Gene & Exon & Nucleotide change & AA change \\
\hline TP53 & 6 & $595-597$ del AAG & Glu 199 del \\
$T P 73$ & 8 & IVS8-15A $>$ G & - \\
\hline
\end{tabular}

\section{DISCUSSION}

TP73 expression is required for neurogenesis of specific neural structures, for pheromonal signaling and for normal fluid dynamics of cerebrospinal fluid. The $p 73$ gene has been considered to be a candidate tumor suppressor gene. Mutations in the $p 73$ gene are rare and have been reported in less than $2 \%$ of all cancers. TP 73 frequently undergoes loss of heterozygosity in breast and colon cancer, neuroblastoma, melanoma, and nonastrocytic brain tumors (Alonso et al., 2001a; Moll and Slade, 2004). It has been reported that there are at least 19 single nucleotide polymorphisms in $p 73$ gene (some in exons and others in introns), but none of them can induce an amino acid change (Alonso et al., 2001b; Ge et al., 2007). We found a polymorphism into the intron 8 , when the base A was replaced by G, but without an amino acid change.

LOH $10 \mathrm{q}$ is most frequent in both primary and secondary glioblastomas. Epidermal growth factor receptor (EGFR) amplification, and PTEN mutations are genetic alterations typical of primary glioblastomas, whereas TP53 mutations are early and frequent genetic alterations in the pathway leading to secondary glioblastomas. The TP53 pathway plays a crucial role in the development of secondary glioblastomas. TP53 mutations are the first detectable genetic alterations in two-thirds of precursor low-grade diffuse astrocytomas; this frequency is similar to that in anaplastic astrocytomas and secondary glioblastomas derived thereof (Ohgaki and Kleihues, 2007). Genetic instability due to the impaired ability of p53 to mediate DNA damage repair further facilitates the acquisition of new genetic abnormalities, leading to malignant progression of an astrocytoma into anaplastic astrocytoma. This is reflected by a high rate of TP53 mutations (60-70\%) in anaplastic astrocytomas and additional genetic abnormalities in the final progression process, leading to a secondary glioblastoma multiforme (Nozaki et al., 1999). In our case, we found an anaplastic astrocytoma that evolved to secondary glioblastoma, with deletion of an AGG codon at position 595-597, resulting in the deletion of Glu in the protein. This deletion occurred in a region of the protein domain and has not been reported before in human tumors. Similar mutations of TP53 have been found to exert a dominant negative effect due to increased stability of the mutant protein compared to that of the wild-type protein (Finlay et al., 1989; Milner and Medcalf, 1991; Petitjean et al., 2007).

We suggest that the mutation found at exon 6 of the gene TP53 is associated with the rapid tumoral progression found in our case, since the mutated p53 may inactivate the wild-type p53 and the p $73 \alpha$ protein, which was conserved here, leading to an increase in cellular instability.

\section{ACKNOWLEDGMENTS}

Research supported by FAPESP, FAEPA, CNPq, and CAPES. Partial support for this study was provided by a grant from Programa de Cooperación Científica con Iberoamérica (Brazil) from the Ministério de Educación, Cultura y Deporte (Spain). 


\section{REFERENCES}

Alonso ME, Bello MJ, Gonzalez-Gomez P, Lomas J, et al. (2001a). Mutation analysis of the p73 gene in nonastrocytic brain tumours. Br. J. Cancer 85: 204-208.

Alonso ME, Bello MJ, Lomas J, Gonzalez-Gomez P, et al. (2001b). Absence of mutation of the p73 gene in astrocytic neoplasms. Int. J. Oncol. 19: 609-612.

Arrowsmith CH (1999). Structure and function in the p53 family. Cell Death Differ. 6: 1169-1173.

Bourdon JC, Deguin-Chambon V, Lelong JC, Dessen P, et al. (1997). Further characterisation of the p53 responsive element - identification of new candidate genes for trans-activation by p53. Oncogene 14: 85-94.

Bourdon JC, Fernandes K, Murray-Zmijewski F, Liu G, et al. (2005). p53 isoforms can regulate p53 transcriptional activity. Genes Dev. 19: 2122-2137.

D’Erchia AM, Tullo A, Pesole G, Saccone C, et al. (2003). p53 gene family: structural, functional and evolutionary features. Curr. Genomics 4: 13-26.

De Laurenzi VD, Catani MV, Terrinoni A, Corazzari M, et al. (1999). Additional complexity in p73: induction by mitogens in lymphoid cells and identification of two new splicing variants epsilon and zeta. Cell Death Differ. 6: 389-390.

Farmer G, Bargonetti J, Zhu H, Friedman P, et al. (1992). Wild-type p53 activates transcription in vitro. Nature 358: 83-86.

Finlay CA, Hinds PW and Levine AJ (1989). The p53 proto-oncogene can act as a suppressor of transformation. Cell 57: 1083-1093.

Ge H, Wang YM, Cao YY, Chen ZF, et al. (2007). The p73 polymorphisms are not associated with susceptibility to esophageal squamous cell carcinoma in a high incidence region of China. Dis. Esophagus 20: 290-296.

Gomez-Manzano C, Fueyo J, Kyritsis AP, McDonnell TJ, et al. (1997). Characterization of p53 and p21 functional interactions in glioma cells en route to apoptosis. J. Natl. Cancer Inst. 89: 1036-1044.

Haas-Kogan DA, Yount G, Haas M, Levi D, et al. (1996). p53-dependent G1 arrest and p53-independent apoptosis influence the radiobiologic response of glioblastoma. Int. J. Radiat. Oncol. Biol. Phys. 36: 95-103.

Holland JF and Frei MDE III (1982). Cancer Medicine. 2nd edn. Lea and Febiger, Philadelphia.

Kleihues P (1998). Subsets of glioblastoma: clinical and histological vs. genetic typing. Brain Pathol. 8: 667-668.

Kleihues P and Cavenee WK (2000). Pathology and Genetics. Tumors of the Nervous System. World Health Organization Classification of Tumours. IARC Press, Lyon.

Ko LJ and Prives C (1996). p53: puzzle and paradigm. Genes Dev. 10: 1054-1072.

Levrero M, De Laurenzi V, Costanzo A, Gong J, et al. (1999). Structure, function and regulation of p63 and p73. Cell Death Differ. 6: 1146-1153.

Levrero M, De Laurenzi V, Costanzo A, Gong J, et al. (2000). The p53/p63/p73 family of transcription factors: overlapping and distinct functions. J. Cell Sci. 113 (Pt 10): 1661-1670.

Melino G, Lu X, Gasco M, Crook T, et al. (2003). Functional regulation of p73 and p63: development and cancer. Trends Biochem. Sci. 28: 663-670.

Michael D and Prados MD (2000). Neoplasms of the Central Nervous System - Molecular Genetics. In: Cancer Medicine. 5th edn (Bast RC, Kufe DW, Pollock RE, Weichselbaum RR, et al., eds.). BC Decker Inc., Hamilton.

Milner J and Medcalf EA (1991). Cotranslation of activated mutant p53 with wild type drives the wild-type p53 protein into the mutant conformation. Cell 65: 765-774.

Moll UM and Slade N (2004). p63 and p73: roles in development and tumor formation. Mol. Cancer Res. 2: 371-386.

Nozaki M, Tada M, Kobayashi H, Zhang CL, et al. (1999). Roles of the functional loss of p53 and other genes in astrocytoma tumorigenesis and progression. Neuro-Oncol. 1: 124-137.

Ohgaki H and Kleihues P (2007). Genetic pathways to primary and secondary glioblastoma. Am. J. Pathol. 170: 1445-1453.

Petitjean A, Mathe E, Kato S, Ishioka C, et al. (2007). Impact of mutant p53 functional properties on TP53 mutation patterns and tumor phenotype: lessons from recent developments in the IARC TP53 database. Hum. Mutat. 28: 622-629.

Reifenberger J, Ring GU, Gies U, Cobbers L, et al. (1996). Analysis of p53 mutation and epidermal growth factor receptor amplification in recurrent gliomas with malignant progression. J. Neuropathol. Exp. Neurol. 55: 822-831.

Rey JA, Bello MJ, Jimenez-Lara AM, Vaquero J, et al. (1992). Loss of heterozygosity for distal markers on 22q in human gliomas. Int. J. Cancer 51: 703-706.

Sbisá E, Catalano D, Grillo G, Licciulli F, et al. (2007). p53FamTaG: a database resource of human p53, p63 and p73 direct target genes combining in silico prediction and microarray data. BMC Bioinformatics 8 (Suppl 1): S20.

Sidransky D, Mikkelsen T, Schwechheimer K, Rosenblum ML, et al. (1992). Clonal expansion of p53 mutant cells is associated with brain tumour progression. Nature 355: 846-847.

Ueda Y, Hijikata M, Takagi S, Chiba T, et al. (1999). New p73 variants with altered C-terminal structures have varied transcriptional activities. Oncogene 18: 4993-4998.

Genetics and Molecular Research 8 (4): 1257-1263 (2009)

CFUNPEC-RP www.funpecrp.com.br 
von Deimling A, Bender B, Louis DN and Wiestler OD (1993). A rapid and non-radioactive PCR based assay for the detection of allelic loss in human gliomas. Neuropathol. Appl. Neurobiol. 19: 524-529.

Vogelstein B, Lane D and Levine AJ (2000). Surfing the p53 network. Nature 408: 307-310.

Vousden KH and Lu X (2002). Live or let die: the cell's response to p53. Nat. Rev. Cancer 2: 594-604.

Watanabe K, Sato K, Biernat W, Tachibana O, et al. (1997). Incidence and timing of p53 mutations during astrocytoma progression in patients with multiple biopsies. Clin. Cancer Res. 3: 523-530.

Zhu J, Jiang J, Zhou W and Chen X (1998). The potential tumor suppressor p73 differentially regulates cellular p53 target genes. Cancer Res. 58: 5061-5065. 